\title{
ЭЛЕМЕНТНЫЙ СТАТУС РЫБ ПРИ ВВЕДЕНИИ В РАЦИОН НАНОЧАСТИЦ ЖЕЛЕЗА, ФЕРМЕНТНЫХ И ПРОБИОТИЧЕСКИХ ПРЕПАРАТОВ
}

\author{
Е.П. Мирошникова, А.Е. Аринжанов*, Ю.В. Килякова \\ Оренбургский государственный университет, 460013, г. Оренбург, пр. Победы 13 \\ *e-mail: arin.azamat@mail.ru
}

РЕЗЮМЕ. Повышение продуктивности объектов аквакультуры неотъемлемо связано с поиском новых кормовых добавок способных повышать интенсивность роста и улучшать физиологическое состояние рыб. Представлены результаты исследования влияния наночастиц железа (НЧ Fe) размером $100 \pm 2$ нм и его комбинированного действия с культурой Bifidobacterium bifidum и ферментным препаратом Ровабио XL на элементный статус рыб при включении в рацион. Показано, что включение в рацион карпа исследуемых добавок положительно влияет на минеральный обмен в организме рыб, которое выражается повышением содержания эссенциальных микроэлементов $\mathrm{Mg}, \mathrm{Co}, \mathrm{Zn}, \mathrm{Cu}, \mathrm{Se}, \mathrm{Fe}, \mathrm{Cr}$ и снижением пула токсических элементов в теле рыб. Наиболее перспективным с позиции повышения живой массы и увеличения ключевых эссенциальных микроэлементов в организме рыб является совместное использование НЧ Fе и пробиотика Bifidobacterium bifidum.

КЛЮЧЕВЫЕ СЛОВА: наночастицЫ, микроэлементы, железо, питание, пробиотики, рыба.

\section{FISH ELEMENTAL STATUS WHEN INCLUDING IRON NANOPARTICLES, ENZYME AND PROBIOTIC PREPARATIONS INTO THE DIET}

\author{
E.P. Miroshnikova, A.E. Arinzhanov*, Y.V. Kilyakova \\ Orenburg State University, 460013, Orenburg, Pr. Pobedy 13 \\ *e-mail: arin.azamat@mail.ru
}

ABSTRACT. Increasing the productivity of aquaculture objects is integrally related to the search for new feed additives which are capable of increasing growth intensity and improving the physiological state of fish. The article presents the study results of the effect of iron nanoparticles with a size of $100 \pm 2 \mathrm{~nm}$, and its combined effect with Bifidobacterium bifidum culture and the Rovabio XL enzyme preparation on the fish elemental status with the diet inclusion. The test additives supplementation in the carp diet positively affects the mineral metabolism in fish body, which is noted by an increase in the content of essential trace elements $\mathrm{Mg}, \mathrm{Co}, \mathrm{Zn}, \mathrm{Cu}, \mathrm{Se}, \mathrm{Fe}, \mathrm{Cr}$ and a decrease in the pool of toxic elements in fish body. The most promising from the point of view of increasing live mass and key essential trace elements in fish body is sharing Fe NP and Bifidobacterium bifidum probiotic.

KEYWORD: nanoparticles, trace elements, iron, nutrition, probiotics, fish.

\section{ВВЕДЕНИЕ}

Для повышения скорости роста и развития рыб в рыбоводстве применяют различные биологически активные добавки: пробиотические и ферментные препараты, микроэлементы и витамины. Цель работы - установить в сравнительном аспекте влияние наночастиц железа совместно с ферментными и пробиотическими препаратами на элементный статус рыб.

\section{МАТЕРИАЛЫ И МЕТОДЫ}

Исследования выполнены на сеголетках карпа массой 10-15 г. По принципу аналогов были сформированы четыре группы $(n=15)$ :

контрольная - основной рацион (ОР);

I опытная - OP с добавлением НЧ Fe (30 мг/кг корма);

II - OP с ферментным препаратом Ровабио XL (6,75 г/кг корма) + НЧ Fe (30 мг/кг корма);

III - OP с пробиотиком Bifidobacterium bifidum $\left(1 \times 10^{7} \mathrm{KOE} / \Gamma, 14\right.$ доз) + НЧ Fе (30 мг/кг корма).

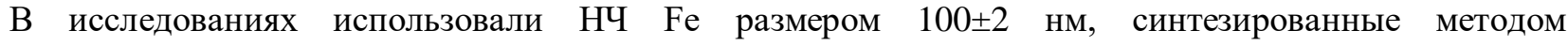
высокотемпературной конденсации на установке Миген-3. Длительность основного учетного периода 56 суток. Микроэлементный анализ проводили в лаборатории АНО «Центр биотической медицины» 
(Москва) методом атомно-эмиссионной и масс-спектрометрии на оборудовании Elan 9000 (Perkin Elmer, США) и Optima 2000 V (Perkin Elmer, США).

\section{РЕЗУЛЬТАТЫ И ОБСУЖДЕНИЕ}

Установлено, что при включении в рацион рыб только НЧ Fе повышается пул эссенциальных элементов по сравнению с контролем: $\mathrm{Mg}$ на 72,2\% ( $p<0,001), \mathrm{Zn}$ на $34 \%(p<0,001), \mathrm{Cu}$ на $18,8 \%(p<0,05)$, Se на $17,5 \%(p<0,001), \mathrm{Cr}$ и Со на $6 \%(p<0,05)$ и $\mathrm{Fe}$ на $2,2 \%$. Включение в рацион $\mathrm{HЧ} \mathrm{Fe}$ и биодобавок свидетельствует о выраженном достоверно значимом увеличении пула эссенциальных элементов на фоне сочетанного действия НЧ и Bifidobacterium bifidum: $\mathrm{Mg}$ на 270\% ( $<<0,001)$, Со на $174 \%$ ( $p<0,001)$, $\mathrm{Zn}$ на $125 \%(p<0,001), \mathrm{Cu}$ на $84 \%(p<0,001)$, Se на $82 \%(p<0,001)$, Fe на $58 \%(p<0,001)$ и $\mathrm{Cr}$ на $36,8 \%$ $(p<0,001)$, что свидетельствует об интенсификации обменных процессов в организме рыб и подтверждается лучшей динамикой роста рыб относительно контроля на $20 \%(p<0,001)$ к концу эксперимента. Выявлена способность используемых добавок снижать уровень токсических элементов, в частности на фоне применения $\mathrm{HЧ} \mathrm{Fe:} \mathrm{Pb}$ на 47\% ( $<<0,001)$, Sn на $36 \%(p<0,001), \mathrm{Hg}$ на $15 \%(p<0,01)$ и $\mathrm{Al}$ на 14\% $(p<0,01)$; на фоне ферментного препарата и НЧ Fe: $\mathrm{Hg}$ на 78\% $(p<0,001)$, Sn на 78\% $(p<0,001)$, $\mathrm{Cd}$ на $45 \%(p<0,001), \mathrm{Al}$ на $43 \%(p<0,001)$ и $\mathrm{Sr}$ на 9\% (p<0,05); на фоне пробиотика и $\mathrm{HЧ} \mathrm{Fe}$ : $\mathrm{Sn}$ на $83 \%$ $(p<0,001)$, Cd на $45 \%(p<0,001)$, Sr на $28 \%(p<0,001)$ и $\mathrm{Al}$ на $19 \%(p<0,01)$ относительно контроля.

\section{ВЫВОДЫ}

Сравнение кормовых добавок ферментного препарата Ровабио XL, культуры Bifidobacterium bifidum и НЧ $\mathrm{Fe}$ показывает, что сочетанное включение последних в рацион повышает интенсивность рыб, благоприятно действует на элементный статус и способствует снижению концентрации токсических элементов в организме рыб, что объясняется синергизмом действия данных препаратов, высокой биодоступностью железа в наноформе на фоне благотворного воздействия п пробиотика на микробиоценоз (Сизова и др., 2011; Xin, et al., 2013).

\section{Сиисок литературы / References}

1. Сизова Е.А., Русакова Е.А., Сизов Ю.А. Некоторые биохимические и морфологически показатели крови при введении в организм наночастиц меди. Известия Оренбургского государственного аграрного университета. 2011; 4(32-1): 308-309.

2. Xin W., Xugang S., Xie C., Li J., Hu J., Yin Y.L., Deng Z.Y. The acute and chronic effects of monosodiuml-glutamate on serum iron and total iron-binding capacity in the jugular artery and vein of pigs. Biol. Trace. Elem. Res. 2013; 153:191-195. 